\title{
Kandungan al-Fātihah Karya Bahrum Rangkuti (Koherensi al-Fätihah dengan Pancasila)
}

\author{
Devi Faizah Yuliana \\ Institut Agama Islam Negeri (IAIN) Kerinci \\ devifaizahy@gmail.com
}

\begin{abstract}
ABSTACT
This paper examines one of Indonesia's interpretations, Kandungan al-Fatihah written by Bahrum Rangkuti, one of Indonesian poets. The main problems studied are: how is the interpretation of Rangkuti towards surah al-Fatihah which is concentrated with Pancasila, how manhaj, thariqah, lawn, and uslub interpretations. This research is a literature study (library research) using the interpretation method of the Qur'an and integrated with the philology approach. The results of the study indicate that Pancasila does not conflict with Islamic teachings. Rangkuti in his book interprets surah al-Fatihah with a cultural vision, then confronts it with Pancasila. Rangkuti explains that the surah al-Fatihah contains five points (ushul); Allah, Rabb al-'Alamin, al-Rahman, al-Rahim, and al-Malik. From these five points, then Rangkuti explained that it also contained an explanation of aspects of politics, social, economy, then linked it to Pancasila. The manhaj used in the work is dominant to tafsir bi al-ra'yi, in addition there are also several interpretations using tafsir bi al-ma'tsur. Thariqah / method of interpretation is tablili (analysis) with lawn / pattern adab al-ijtima'i (social society). While uslub (systematic) the interpretation begins with an explanation of alFatihah, the purpose of each verse, then the content of surah al-Fatihah is described in the chapters contained in the book to the end.
\end{abstract}

Keyword: Interpretation, Pancasila, al-Fatihah, Bahrum Rangkuti

\section{ABSTRAK}

Tulisan ini mengkaji tentang salah satu karya tafsir Indonesia, yakni buku Kandungan Al-Fatihah yang ditulis oleh Bahrum Rangkuti, salah satu sastrawan Indonesia. Pokok permasalahan yang dikaji adalah: bagaimana penafsiran Rangkuti terhadap surah al-Fatihah yang dikoherensikan dengan Pancasila, bagaimana manhaj, thariqah, lawn, dan uslub tafsirnya. Penelitian ini merupakan studi kepustakaan (library research) dengan menggunakan metodologi penafsiran al-Qur'an dan diintegrasikan dengan pendekatan filologi. Hasil penelitian menunjukkan bahwa Pancasila tidak bertentangan dengan ajaran Islam. Rangkuti dalam bukunya menafsirkan surah al- 
Fatihah dengan visi kebudayaan, lalu menghadapkannya dengan Pancasila. Rangkuti menjelaskan bahwa surah al-Fatihah mengandung lima pokok (ushul), yaitu Allah, Rabb al-'Alamin, al-Rahman, al-Rabim, dan al-Malik. Dari lima pokok ini, kemudian Rangkuti menjelaskan bahwa di dalamnya juga mengandung penjelasan tentang aspek politik, sosial, ekonomi, lalu mengaitkannya dengan Pancasila. Adapun manhaj yang digunakan dalam karya tersebut adalah dominan ke tafsir bi al-rayi di samping juga terdapat beberapa penafsirannya menggunakan tafsir bi al-ma'tsur. Thariqah/ metode tafsirnya adalah tablili (analisis) dengan lawn/corak adab al-ijtima'i (sosial kemasyarakatan). Sedangkan uslub (sistematika) tafsirnya dimulai dengan penjelasan tentang al-Fatihah, maksud masing-masing ayat, selanjutnya diuraikan kandungan surah al-Fatihah ke dalam bab-bab yang terdapat dalam buku tersebut sampai akhir.

Kata Kunci: Tafsir, al-Fatihah, Pancasila, Bahrum Rangkuti

\section{PENDAHULUAN}

Diskursus seputar peran Pancasila sebagai dasar negara, falsafah dan pandangan hidup bangsa Indonesia dengan Islam masih saja diperdebatkan hingga masa ini. Sebagian kalangan umat Islam di Indonesia masih enggan mengakui peran Pancasila sebagai dasar negara dan pandangan hidup bangsa dengan dalih bahwa Pancasila merupakan hukum buatan manusia bukan berasal dari konstitusi (hukum) Allah. Bahkan ada juga sebagian yang menyebutnya sebagai "tagut".

Pancasila sebagai dasar negara merupakan sebuah perjanjian luhur dan hasil kesepakatan bersama para pendiri bangsa (founding fathers) Indonesia. Hasil ijtihad politik kebangsaan ini juga didasarkan pada kenyataan multikulturalisme bangsa Indonesia. Sebagai falsafah hidup bangsa, hakekat nilai-nilai Pancasila telah hidup dan diamalkan oleh bangsa Indonesia sejak negara ini belum berbentuk. Artinya, rumusan Pancasila sebagaimana tertuang dalam alinea keempat UUD 1945 sebenarnya merupakan refleksi dari falsafah dan budaya bangsa, termasuk di dalamnya bersumber dan terinspirasi dari nilai-nilai dan ajaran agama yang dianut bangsa Indonesia.

Pemahaman tentang adanya pertentangan antara Pancasila dan Islam patut untuk diluruskan. Apabila dikaji dan dipahami secara holistik kepada ajaran Islam, Pancasila merupakan solusi konkrit dan strategis dalam 
menghadapi kebhinekaan yang terdapat di Indonesia. Pancasila menjadi jalan tengah, tidak ke kiri atau berhaluan sekuler yang memisahkan diri dari ajaran agama, tidak pula mengarah kepada ekstremisme ke kanan, atau berhaluan Islamisme yang mendasarkan diri pada penegakan syariat Islam dengan menggaungkan tuntutan penerapan syariat Islam sebagai upaya untuk mengganti Pancasila dengan dasar negara Islam.

Pada rapat pleno ke-26 MUI bertema 'Tantangan dan Ancaman terhadap Kedaulatan Negara' yang digelar di gedung MUI, Jalan Proklamasi, Jakarta Pusat, Ketua Dewan pertimbangan MUI, Din Syamsuddin mengatakan bahwa Pancasila dan Islam sebagai sesuatu yang berbeda. Meski demikian, antara Pancasila dan Islam punya kesamaan nilai untuk mempertahankan kedaulatan Indonesia. Menurutnya, meskipun Islam merupakan ajaran yang didasarkan pada konstitusi (hukum) Allah, sedangkan Pancasila adalah hasil dari pikiran manusia, bukan berarti dengan sertamerta keduanya menjadi saling bertentangan, bahkan keduanya saling bersesuaian. Oleh karena itu, menurutnya nilai ajaran agama Islam sesuai dengan Pancasila (Matondang, 2018).

Ibn Taimiyah menjelaskan dalam al-Siyasah al-Syariyyah bahwa wilayah (organisasi politik) bagi kehidupan kolektif manusia merupakan keperluan agama terpenting. Tanpa topangnya, agama tidak akan tegak dengan kokoh (Taimiyah, 1996, p. 138) Negara bagi Ibn Taimiyah berfungsi sebagai institusi politik untuk melaksakan perintah-perintah Allah dan mencegah laranganlarangan-Nya. Selanjutnya ia mengatakan: "dan karena Allah mewajibkan amar ma'ruf nahi munkar serta menolong pihak yang teraniaya, tidak mungkin sempurna kecuali dengan kekuatan dan kekuasaan (Taimiyah, 1996, p. 138). Oleh sebab itu menurut penulis, jika dikaitkan hal ini dengan dirumuskannya Pancasila sebagai dasar negara Indonesia yang merupakan 
manifistasi dari upaya pembentukan negara untuk mencapai kemaslahatan bangsa sebagai solusi strategis pengokoh persatuan dan kesatuan bangsa Indonesia didasarkan pada kenyataan keadaan masyarakat yang multikultural, tidaklah bertentangan dengan ajaran Islam.

Tulisan ini akan mengkaji relasi antara Islam dan Pancasila untuk menunjukkan bahwa Pancasila tidak bertentangan dengan Islam melalui pendekatan interpretasi al-Qur'an dengan mengkaji salah satu buku karya Bahrum Rangkuti yang berjudul Kandungan al-Fatihah.

Al-Qur'an adalah kitab Allah yang diturunkan kepada nabi Muhammad saw, menjadi pedoman hidup (way of life) bagi manusia terutama umat Islam. Al-Qur'an merupakan kitab petunjuk yang berisikan tentang keimanan, ibadah, ilmu pengetahuan, kisah-kisah, adab-adab dan peraturanperaturan yang mengatur tingkah laku dan tata cara hidup manusia, baik sebagai makhluk individu maupun sosial. Oleh karena itu, al-Qur'an merupakan sumber utama bagi umat Islam yang ingin menggapai kesuksesan di dunia dan akhirat, yakni dengan mempelajari dan mengamalkan kandungannya. Oleh sebab itu, penelitian tentang adanya relasi antara Pancasila dan Islam melalui pendekatan penafsiran al-Qur'an dengan menggunakan salah satu karya tafsir Indonesia layak dilakukan.

Buku Kandungan al-Fatihah merupakan salah satu karya tafsir al-Qur'an khusus pada surah al-Fatihah. Buku ini sangat menarik karena pengarang menguraikan kandungan al-Fatihah berawal dari pandangannya terhadap kebudayaan Indonesia dengan mengeksplorasi Pancasila didasarkan pada kandungan surat al-Fatihah, di mana Pancasila merupakan dasar dan falsafah bangsa Indonesia. Penelitian ini akan mengkaji tentang buku Kandungan AlFatihah karya Bahrum Rangkuti dengan menggunakan metodologi tafsir sebagaimana yang diformulasikan oleh Abd al-Hay al-Farmawi dan diintegrasikan dengan pendekatan filologi. 
Kandungan al-Fätihah Karya Bahrum Rangkuti

(Koherensi al-Fätibah dengan Pancasila)

\section{PEMBAHASAN}

\section{Riwayat Hidup}

Nama lengkap penulis buku Kandungan al-Fatibah adalah Bahrum Rangkuti. Rangkuti merupakan marganya (marga adalah kelompok kekerabatan berdasarkan garis keturunan ayah atau patrilinear. Ini adalah di antara ciri khas orang Medan dan Mandailing (Pengertian Marga dan Tarambo , 2008), yakni salah satu marga yang ada di Medan, tempat asalnya. Bahrum Rangkuti lahir pada tanggal 7 Agustus 1919 di Pulau Tagor, Galang, Riau, Sumatera Timur, dan wafat pada tanggal 13 Agustus 1977 di Jakarta (B. Setiawan, 2004, p. 93) (Ihsan, 1980, p. 361). Ayahnya bernama M. Tosib Rangkuti, dan ibunya Siti Hanifah Siregar. Walaupun Bahrum lahir di Riau, tapi ia adalah putra Mandailing asli (Medan). Bahrum dibesarkan oleh keluarga bernuansa Islam yang kental, ayahnya mendalami tarekat, dan ibunya menyenangi tasauf dan mistik (Bumi Bebas, 2007).

Bahrum adalah seorang penulis esai dan cerita pendek yang menaruh minat besar terhadap agama dan filsafat (Ihsan, 1980). Pendidikan formal Bahrum berawal di kota Medan. Tingkatan SD (Sekolah Dasar) Bahrum di HIS (Hollands Inlandse School), sebuah sekolah Belanda di Medan. Kemudian Bahrum melanjutkan pendidikannya pada tingkat Menengah Pertama di HBS (Hogere Burger School). Setelah itu, Bahum melanjutkan studinya di AMS (Algemene Middekbare School) di Yogyakarta, dan menyelesaikannya pada tahun 1939. Lalu Bahrum kuliah di Faculteit de Lettern pada tahun 1939-1941, yang kemudian menjadi Fakultas Sastra di Universitas Indonesia (Bumi Bebas, 2007) (Ihsan, 1980).

Pada tahun 1950, Bahrum juga pernah belajar di Jamiatul Mubasheren, Rabwah, di Pakistan (Ihsan, 1980). Rabwah adalah sebuah desa kecil di tepi sungai Cenaab, tempat latihan para misionaris Islam yang bertugas ke seluruh dunia. Tapi, Bahrum tidak berminat untuk menjadi 
misionaris. Sekembali dari Pakistan, Bahrum melanjutkan kuliahnya di Fakultas Sastra di Universitas Indonesia sampai menjadi sarjana penuh pada tahun 1960. Bahrum menguasai tujuh bahasa, yaitu Arab, Inggris, Prancis, Belanda, Jerman, Urdu, dan bahasa daerahnya (Mandailing). Kemudian Bahrum bekerja sebagai penerjemah Bahasa Inggris dan Prancis, di samping sebagai wartawan freelance dan guru di sebuah Sekolah Menengah Atas di Jakarta (Bumi Bebas, 2007).

Bahrum pernah ceramah tentang aspek sosial hari raya di depan para perwira ALRI pada saat Angkatan Laut RI dipimpin oleh Edi Martadinata. Ternyata ceramahnya itu memukau Edi dan para pewira. Lalu Edi meminta Bahrum untuk menjadi Ketua Dinas Perawatan Rohani Islam di AL dengan pangkat kolonel tituler. Walaupun telah menjadi kolonel ALRI, Bahrum tidak mengabaikan minat dan kecintaannya terhadap dunia sastra, hal ini terlihat saat Bahrum membacakan sajak-sajak Iqbal, pengarang dari Pakistan di Pusat Kesenian Jakarta pada tanggal 28 September 1969 (Bumi Bebas, 2007).

Pada tahun 1970 sampai 1977, Bahrum menjadi Sekretaris Jenderal Departemen Agama (Ihsan, 1980). Tahun 1963 ia dikukuhkan menjadi guru besar Universitas Islam Sumatera Utara, Medan, dan pada tahun1976 guru besar Institut Agama Islam Negeri (IAIN) Syarif Hidayatullah Jakarta (B. Setiawan, 2004).

\section{Karya-karya}

Puisi

\section{Sajak-sajak yang Sudah Diterbitkan}

“Tuhanku" Pandji Poestaka (1943)

"Langit dan Bumi Baru" Pandji Poestaka (1944)

“Peperangan Badar" Pandji Poestaka (1944)

"Prajurit Rohani” Pandji Poestaka (1944)

“Akibat" Pantja Raja (1946)

"Borobudur" Pantja Raja (1946)

"Cita-Cita" Pantja Raja (1946) 
Kandungan al-Fätihah Karya Bahrum Rangkuti

(Koherensi al-Fätibah dengan Pancasila)

“Doa Makam" Pantja Raja (1946)

"Hidupku" Pantja Raja (1946)

“Insyaf” Pantja Raja (1946)

“Kembali” Pantja Raja (1946)

"Laut Kenangan" Pantja Raja (1946)

"Sakura" Pantja Raja (1946)

“Tugu Kenangan" Pantja Raja (1946)

"Laila" Gema Suasana (1948)

"Pasar Ikan" Gema (1948)

"Sajak-Sajak Muhammad Iqbal" Siasat (1951)

"Syuhada" Hikmah (1952)

"Iqbal” Hikmah (1953)

"Malam dari Segala Malam" Gema Islam (1962)

"Pesan" Gema Islam (1966)

"Nafiri Ciputat" Horison (1970)

"Anak-Anakku" Horison (1971)

"Dunia Baru" Horison (1971)

"Ayahanda" Horison (1971)

"Bunda" Horison (1971)

"Lebaran di Tengah-Tengah Gelandangan" Horison (1971)

"Mercon Malam Takbiran" Horison (1971)

"Pejuang" Horison (1971)

"Rumah" Horison (1971)

"Sembahyang di Taman HI" Horison (1971)

"Tuhan di Tengah-Tengah Insan" Horison (1971)

"Sumbangsih" Koninklijke Boekhandel dan Drukkery G.Kollf dan Co

"Hikmah Puasa dan Idul Fitri" Koninklijke Boekhandel dan Drukkery G.

Kollf dan Co

\section{Sajak-sajak yang Belum Diterbitkan dan Tahun Ciptaannya:}

"Tao Toba" (1970)

"Sipirok" (1970)

"Natalandi Gita Bahari” (t.th.)

"Nunukan" (1970)

"Mesjid di Tanjung Selor" (1970)

"Ka’bah" (1971)

"Bungan Bondar" (1971) 
Kandungan al-Fätihah Karya Bahrum Rangkuti

(Koherensi al-Fätibah dengan Pancasila)

"Mina" (1971)

"Madinah" (1971)

"Arafah" (1971)

"Makkah" (1971)

"Hajir" (1971)

"Nisbah" (1971)

"Yang Genap dan Yang Ganjil" (1971)

"Bengkel Manusia" (t.th.)

"meluruskan bahtera" (1973)

"Nyanyian di Pohon Kelapa" (1973)

"Mi'raj" (t.th.)

"kepada Biniku A. Bara" (t.th.)

"Isa a.s." (1969)

"Idul Fitri" (t.th.)

"Mula Segala" (1969)

"Muhammad s.a.w." (1969)

"Beton, Beling, dan Besi" (t.th.)

"Laut Lepas Menanti" (t.th.) (PDS. H.B. Jassin)

\section{Drama}

"Laila Majenun" Gema Suasana (1949)

"Sinar memancar dari Jabal Ennur" Indonesia (1949)

"Asmaran Dahana" Indonesia (1949)

"Arjuna Wiwaha"

Cerpen

"Ditolong Arwah" Pandji Poestaka (1936)

"Rindu" Poedjangga Baroe (1941)

"Renungan Jiwa" Pandji Poestaka (1942)

"Ngobrol dengan Cak Lahama" gema Suasana (1946)

"Sayuti Parinduri Alfaghuru" atau "Antero Krisis Cita, Moral, dan benda" Zenith (1952)

"Laut, Perempuan, dan Tuhan" Gema Tanah Air (1969)

\section{Esai}

"Setahun di negeri Bulan Bintang I" Zenith (1951)

"Setahun di negeri Bulan Bintang II" Zenith (1951)

"Setahun di negeri Bulan Bintang II" Zenith (1951)

"Angka dan Penjelmaannya" Zenith (1951) 
Kandungan al-Fätihah Karya Bahrum Rangkuti

(Koherensi al-Fätibah dengan Pancasila)

"Pengantar kepad Cita Iqbal" Indonesia (1953)

"Kandungan Al Fatihah" (1953)

"Nabi Kita" Bacaan untuk Anak-anak (t.th.)

"Islam dan kesusastraan Indonesia Modern": skripsi s-1 (1961).

Diterjemahkan ke dalam bahasa Inggris dengan judul "Islam and "Modern

Indonesian Literature"

"Pramudya Ananta Toer; dan Karya seninya" (1963)

"Terapan Hikmah Isra dan Mikraj dalam kehidupan Sehari-hari” Operasi (1968)

"Muhammad Iqbal Pemikir dan Penyair" ceramah di TIM (1969)

"Ceramah Tentang Cita-Cita M. Iqbal" TIM (1976)

“Al Quran, Sejarah, dan Kebudayaan” Pidato pengukuhan sebagai Guru

Besar (1976)

"Sejarah Indonesia I dan II"

"Metode Mempelajari Tafsir Qur'an dan Bahasa Arab"

"Sejarah Khalifah Usman r.a"

"Sejarah Nabi Muhammad s.a.w"

"Islam dan Pembangunan"

"The Spritual Wealth in Islam"

\section{Terjemahan}

"Puisi Dunia" karya Sophocles dari Antagone (1948)

"Dengan Benih Kemerdekaan" karya Alexander Pushkin (1949)

“Kepada Penyair” karya M. Iqbal

"Insan dan Alam" karya M. Iqbal (1953)

"Waktu itu Adalah Pedang" karya M. Iqbal (1953)

“Iqbal Di Hadapan Rumi” karya M. Iqbal (1953)

"Soledad Montoya" karya Lorca

"Lintas Sejarah Dunia" karya Jawaharlal Nehru

"Asrar-J. Khudi" karya Dr. Muhammad Iqbal.

\section{Pendekatan (manhaj) Tafsir}

Dalam buku Kandungan al-Fatihah, Rangkuti menjelaskan bahwa surah al-Fatihah mengandung lima usul, yaitu Allah, Rabb al-'Alamin, al-Rahman, al-Rahim, dan al-Malik. Cita lima ushul ini didapatinya dalam buku Tafsir Kabir karya M.B Mahmud Ahmad (M.B Mahmud Ahmad adalah guru Bahrum ketika belajar di Rabwah, Pakistan) (Rangkuti, 1976, p. 22). Dalam menjelaskan lima 
usbul ini, di antaranya dijelaskan dengan pengetahuannya dalam berbahasa Arab, juga dengan ayat lain yang menerangkan di antara lima ushul itu, dan dipertegas dengan nalarnya. Sebagai contoh, penjelasannya tentang Allah sebagai berikut (Rangkuti, 1976, p. 26-27).

"Kita mulai dengan nama Allah, yakni nama zat dari al-Khalik yang telah menjadikan dan mengatur alam semesta ini. Lafaz Allah ini bukanlah terjadi dari al + ilahu sebagai banyak dikemukakan oleh ahliahli ketimuran. Dalam bahasa Arab, lafaz Allah belumlah pernah digunakan oleh salah satu kabilah Arab untuk menyatakan dewa-dewa mereka dulu sebelum kedatangan agama Islam. Allah menurut Qur'an dan kamus-kamus bahasa Arab ialah nama dari zat yang tunggal segala lagi sendiri, Yang mempunyai sifat-sifat utama, lagi jauhlah Dia dari segala noda dan cela. Nama-nama dalam bahasa lain yang melukiskan Tuhan adalah deskriptif atau atributif dan sering pula mengandung arti banyak, tetapi lafaz Allah tunggal dan bukan isim musytaq, artinya perkataan itu masuk kata-kata yang tidak bisa menjelmakan "afleidingen" atau juga yang bukan diasalkan dari kata lain. Ada pula ahli-ahli bahasa Arab sendiri seperti al-Khauri alSyartuti dalam Aqrabnya menuliskan bahwa lafaz Allah berasal dari kata kerja laha yang berarti: tinggi atau unggul, tetapi teori ahli bahasa Arab itu sudah pula disangkal oleh sarjana-sarjana lain yang datang kemudian. Demikian juga Noldeke seorang orientalist Jerman menerangkan dalam Biblica jilid III bahwa lafaz Allah itu berasal dari perkataan Ibrani purba $A l i$, yang panjangnya zaman berubah menjadi Allah dalam bahasa Arab. Keterangan Dr. Nolkede ini telah dibantah oleh berbagai sarjana Muslim sendiri, antaranya B. Mahmud Ahmad dalam Tafsir Kabirnya dengan mengemukakan berbagai macam keterangan bahwa perkataan Allah itu adalah penjelmaan dari Qur'an sendiri, dan dalam bahasa Arab al-Qur'an. Tegasnya hanyalah bahasa Arab yang dapat mengemukakan nama Zat Tuhan, yakni Allah, yang mengandung arti azali dan abadi."

Dari lima usul ini, kemudian Rangkuti menjelaskan bahwa di dalamnya juga mengandung penjelasan tentang aspek politik, sosial, ekonomi, dan kemudian mengaitkannya dengan Pancasila. Dalam menjelaskan aspekaspek ini, Bahrum juga menggunakan beberapa ayat al-Qur'an yang 
berkenaan dengan masing-masing aspek. Dari ayat pendukung tersebut, Bahrum menerangkan lagi lebih lanjut penalarannya terhadap ayat tersebut.

Sebagai contoh, penjelasannya tentang al-Fatihah mengenai politik, di dalam buku itu dijelaskan bahwa berdasarkan atas paham tauhid sebagai penjelmaan dari nama Allah, dalam al-Fatihah dihidupkan kembali teori tentang hak ketuhanan dari raja atau para pengendali pemerintahan, yakni dengan perkataan amanah untuk menggambarkan konsepsi pemerintahan sebagaimana dalam firman Allah dalam surah al-Nisa' ayat 58, yaitu:

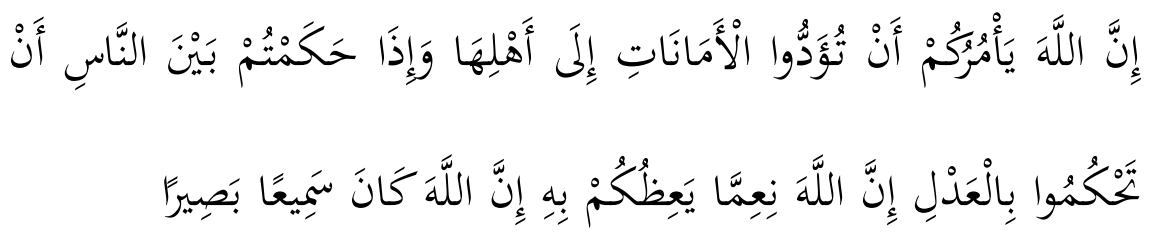

Artinya: "Sungguh, Allah menyuruhmu menyampaikan amanat kepada yang berhak menerimanya, dan apabila kamu menetapkan hukum di antara manusia hendaknya kamu menetapkannya dengan adil. Sungguh, Allah sebaik-baik yang memberi pengajaran kepadamu. Sungguh, Allah Maha Mendengar, Maha Melihat. ${ }^{1}$

Setelah itu, Rangkuti menjelaskan kandungan ayat tersebut dengan nalarnya. Contohnya adalah penjelasan Rangkuti bahwa dalam bagian pertama ayat tersebut ditujukan kepada rakyat, agar memilih para pengendali pemerintahan, hal ini adalah amanat, dan rakyat seharusnya memilih orang yang benar-benar ahli dalam urusan pemerintahan (Rangkuti, 1976, p. 4243).

${ }^{1}$ Dalam buku Kandungan al-Fatihah hanya disebutkan terjemahan Bahrum terhadap ayat ini, yaitu: :'Sesungguhnya Allah memerintahkan kepada kamu (jadi bukan engkau!) supaya meng-amanatkan tugas pemerintahan kepada mereka yang benar-benar ahli dalamnya dan mereka yang telah menjadi para pengendali pemerintahan, haruslah bertindak adil dalam urusan pemerintahan; Allah melukiskan kepada kamu apa yang utama dan sebaik-baiknya, sesungguhnya Dialah yang Maha Pendengar dan Maha Melihat." Bahrum Rangkuti, Kandungan al-Fatihah..., 42. 
Sementara itu, pada awal penjelasan Rangkuti terhadap surah alFatihah, disebutkan terjemahannya terhadap hadis yang menjelaskan tentang keutamaan surah ini, yakni:

"Taklah pernah Tuhan menurunkan sebuah kitab semisal al-Fatihah yang tujuh ayatnya ini, baik dalam Injil maupun dalam Taurah, dan Allah Ta'ala berfirman mengenai al-Fatihah bahwa surah ini terbagi antara Aku dan hamba-hambaKu dan mereka yang mendo'a serta mengamalkan isi surah itu pastilah Kuterima dan Kuwujudkan kehendak mereka."

Dari pemahaman Rangkuti (1976) terhadap hadis yang diterjemahkannya tersebut, dikelompokkanlah surah al-Fatihah menjadi dua bagian, yakni; pertama mengenai Tuhan (khusus bagi Allah); dan yang kedua bagian insan (khusus bagi manusia) (p. 15).

Dilihat dari penjelasannya terhadap masing-masing ayat dalam surah al-Fatihah, maka tampak adanya aspek tasauf. Sebagai contoh, penjelasan Rangkuti terhadap maksud dari lafaz hamdalah ${ }^{2}$ dalam surah al-Fatihah sebagai berikut (Rangkuti, 1976, p. 15-16):

"Segala puja dan puji kepunyaanKu semata. Puja dan puji kepada zatzat lain atau barang-barang di dunia ini hanyalah sekundair sebab semuanya itu ialah pancaran sifat-sifatKu. Oleh sebab itu, janganlah kau terpedaya oleh segala itu wahai manusia. Akulah sebenarnya yang menyebabkan pelbagai solek, gaya dan nan indah di dunia ini dan di alam yang akan datang. Akulah yang memiliki bumi dan langit dan apa yang ada di antaranya. Aku yang menjelmakan bangsa demi bangsa, negara dan ummat, dan Aku pula yang meruntuhkannya di zaman yang silam, kini dan akan datang. Maka beribadatlah kepadaKu, wahai manusia sebab Akulah Tuhan yang menjawab setiap do'a dan panggilan mereka yang sembahyang kepadaKu yang memujiKu. Tetapi belajarlah membebaskan kerja dan amal yang baikbaik di dunia ini: peliharalah diri dan keluargamu, bangsa dan ummat manusia, sebagaimana Aku memelihara dan menjaga mereka semua. Dan belajarlah melakukan pengnafian diri bagi sesama manusia agar kau kian dekat kepaaKu. Jadi kenalilah Aku dengan sifat-sifatKu.

${ }^{2}$ Lafaz yang dimaksud adalah ayat الحمد لهّ رب العالمين 
Hanya saja dengan mengetahui apa sifat-sifatKu itu, dapatlah kau kenal kepadaKu. Renungkan dan ttumbuhkanlah sifat-sifatKu itu dalam dirimu supaya kau menjadi seperti Aku. Dan ttidak kau perdapat sesuatu yang terpuji di langit dan di bumi, melainkan itu semuanya adalah pancaran WajahKu jua."

Setiap ayat dari ayat kedua sampai terakhir dalam surah al-Fatihah, Rangkuti (1976) selalu menjelaskan masing-masing ayat tersebut seperti ini. Lalu dijelaskanlah maksud ayat-ayat dalam surah al-Fatihah dari ayat pertama sampai terakhir (p. 22). Kemudian pada bagian selanjutnya, Rangkuti menguraikan kandungan surah al-Fatihah dari aspek politik, sosial, ekonomi, dan keselarasannya dengan Pancasila.

Berdasarkan penjelasan di atas, maka penulis menyimpulkan bahwa pendekatan (manhaj) yang digunakan Rangkuti dalam buku Kandungan alFatibah adalah dominan dengan $r a^{\prime} y i^{3}$. Penulis mengategorikannya kepada ra'yi yang mahmudah (terpuji). Meskipun ada beberapa yang dijelaskan dengan ayat, tapi dengan terjemahan yang berasal dari pikirannya sendiri yang memang mempunyai latar belakang kompetensi bahasa Arab.

Sumber yang digunakan Rangkuti dalam buku ini adalah sebagai berikut: Pertama, Tafsir Kabir jilid I dan II oleh B.M. Ahmad, kedua, Tafsir Muhammad Abduh karya Moh. Rasyid Ridha, ketiga Wasiat Lama, keempat

${ }^{3}$ Ra'yi lebih dekat maknanya kepada ijtihad (kebebasan penggunaan akal) yang didasarkan atas prinsip-prinsip yang benar, menggunakan akal sehat dan prasyarat yang ketat. Tafsir bi al-ra'yi dibagi dalam dua kategori; tafsir yang terpuji dan yang tercela. Tafsir terpuji ialah tafsir Qur'an yang didasarkan dari ijtihad yang jauh dari kebodohan dan penyimpangan. Tafsir ini sesuai dengan peraturan bahasa Arab. Karena tafsir ini tergantung kepada metodologi yang tepat dalam memahami ayat-ayat al-Qur'an. Tafsir yang tercela ialah tafsir al-Qur'an tanpa dibarengi dengan pengetahuan yang benar, yaitu tafsir yang didasarkan hanya kepada keinginan seseorang dengan mengabaikan peraturan dan persyaratan tata bahasa serta kaidah-kaidah hukum Islam. Tafsir ini merupakan penjelasan Kalamullah atas dasar pikiran atau aliran yang sesat dan penuh dengan bid'ah atau inovasi yang menyimpang. Thameem Ushama, Metodologi Tafsir al-Qur'an Kajian Kritis, Objektif dan Komprehensif (Jakarta: Riora Cipta, 2000), 14-15. Bandingkan dengan Yunus Hasan Abidu, Dirasat wa Mabahits fi Tarikh al-Tafsir wa Manabij al-Mufassirin, penerj. Qadirun Nur dan Ahmad Musyafiq, Tafsir al-Qur'an: Sejarah Tafsir dan Metode Para Mufasir (Jakarta: Gaya Media Pratama, 2007), 8 
Fathul Bayan, kelima Bentuk Ekonomi Dunia, terjemahan Bahrum Rangkuti dari Islam Iqtisadi ka nizaam, keenam Cibawaih oleh Abu al-Basyr 'Amr Sibawaih, ketujuh Sunan Baihaqi karya Abu Bakr Ahmad bin Husain alBaihaqi, kedelapan Tafsir Qur'an oleh Imam Abu Ja'far Muhammad ibn Jarir, kesembilan Tafsir Kabir oleh Imam Muhammad Fakhruddin Razi, kesepulub Qurtubi oleh Abu 'Abdullah Muhammad bin Ahmad al-Qurthubi.

Kesebelas Arabic- English Lexicon oleh E. W. Lande, keduabelas Principles of Political Science and Goverment oleh Biman Behari Majumdar, Ph. D, ketigabelas Civilization on Trial oleh Arnold J. Toynbee, keempatbelas Asrari Khudi oleh Dr. Muh. Iqbal, kelimabelas Iqbal, His Art and Thought karya Syed Abdul Vahid, B.Sc., M.A, keenambelas Pancasila oleh Asmara Hati (H.R), ketujubbelas Indonesia (Nomor Kongres Kebudayaan ke-2 di Bandung), kedelapan belas Lahirnya Pancasila, kesembilanbelas The New World Order of Islam oleh M.B. Ahmad terjemahan Prof. M. Islam, terakhir keduapulub Visage de 'Tislam oleh M.B. Ahmad terjemahan Prof. M. Islam.

\section{Metodologi (thariqah) Tafsir}

Menurut penulis, metode (thariqah) yang digunakan dalam buku ini adalah tablili, Metode tahlili suatu metode tafsir yang berusaha menggali makna kandungan al-Qur'an dari ayat-ayat al-Qur'an dari seluruh aspeknya. Menafsirkan ayat-ayat al-Qur'an dengan memaparkan segala aspek yang terkandung di dalam ayat-ayat yang ditafsirkan itu serta menerangkan makna-makna yang tercakup di dalamnya sesuai dengan keahlian dan kecendrungan mufasir yang menafsirkan ayat tersebut (Baidan, 2000, p. 31) (Al-Farmawi, 1977, p. 24) karena pada awal penafsiran Rangkuti terhadap surah al-Fatihah, dilakukan secara berurut yang terletak pada bagian II dari buku ini. Pada bagian-bagian selanjutnya sampai terakhir, dijelaskan tentang kandungan surah al-Fatihah ditinjau dari berbagai aspek yang diuraikan dalam buku ini yang merupakan rincian dari 
pemahamannya terhadap surah ini. Hal ini bisa dilihat pada daftar isi atau kandungan buku yang penulis letakkan di bagian uslub tafsir.

\section{Corak (lawn) Tafsir}

Penulisan buku ini terinspirasi dari dialog antara Rangkuti dengan dua orang sahabatnya yaitu Sumantri dan Amir Sudoro tentang cita mereka mulai dari masalah mistik hingga ontologi, filsafat, theologi, ekonomi yang kemudian dimuarakan oleh Bahrum ke Pancasila.

Rangkuti menjelaskan bahwa penafsirannya berdasarkan visi kebudayaan. Artinya ia lebih menitikberatkan kepada visi al-Fatihah dalam konteks kebudayaan bangsa Indonesia dengan Pancasila sebagai sandingannya, di mana Pancasila merupakan dasar negara, falsafah dan pandangan hidup bangsa Indonesia. Maka lawn penafsiran dalam buku ini menurut penulis adalah adab al-ijtima’i (sosial kemasyarakatan).

Sebagai contoh dalam bab X dengan tema "Al-Fatihah dengan Pancasila". Bahrum mengawali tema ini dengan realitas sosial yang melahirkan dua kubu dalam memandang Pancasila, yaitu kelompok yang "haram" menpancasilakan al-Fatihah, dan kelompok yang menganggap "gila" meng-alfatihahkan Pancasila (Rangkuti, 1976, p. 115).

Dalam uraiannya, Rangkuti mencoba mengungkap keselarasan antara al-Fatihah sebagai hukum Tuhan dengan Pancasila sebagai hukum manusia. Menurutnya, al-Fatihah dan Pancasila memilki kesesuaian dalam menata kehidupan berbangsa di Indonesia. Jadi, inti dari ajaran al-Fatihah pada dasarnya juga diakomodasi dalam Pancasila.

\section{Sistematika (uslub) Tafsir}

Buku "Kandungan al-Fatihah" karya Bahrum Rangkuti ini dilihat dari kondisi fisiknya, merupakan cetakan kedelapan, diterbitkan oleh Bulan Bintang pada tahun 1976, terdiri dari 144 halaman dari halaman setelah sampul sampai akhir. Sampulnya tebal (hard cover), bewarna blasteran kuning 
dan biru. Setelah sampul, ada halaman yang hanya bertuliskan "Kandungan Al-Fatihah" di bagian atas. Halaman kedua adalah surah al-Fatihah. Halaman ketiga bertuliskan nama pengarang, yaitu Drs. H. Bahrum Rangkuti di bagian atas kertas, bagian tengahnya "Kandungan Al-Fatihah", dan di bawahnya data tentang penertbit, yakni "Penerbit Bulan Bintang Jakarta Kramat Kwitang I/8 Telp. 42883". Halaman keempat hanya bertuliskan "Cetakan kedelapan (Bulan Bintang) - 1976”. Selanjutnya kata pengantar dari pengarang pada tanggal 21 Januari tahun 1954 di Jakarta. Selanjutnya daftar isi yang diistilahkan oleh Rangkuti dengan "Kandungan Buku", yaitu:

\section{"KANDUNGAN BUKU:}

Pengantar . .5

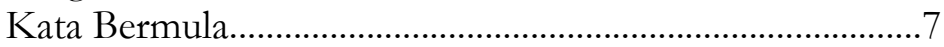

Thema Surat al-Fatihah......................................................14

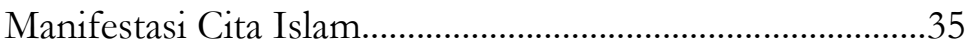

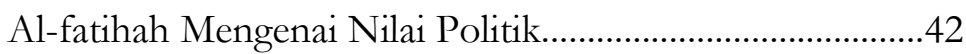

Sosialisme dari Tinjauan Sinar al-Fatihah.............................56

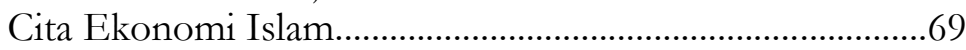

Latar Belakang Larangan Islam..............................................88

Cara Islam Mensirkulasikan Uang/Harta..............................92

Lingkupan Sejarah Dalam Untaian Dialog............................97

Al-fatihah Dengan Pancasila.....................................................115

Tirta Rohaniah Bagi Menyuburkan Pancasila......................125

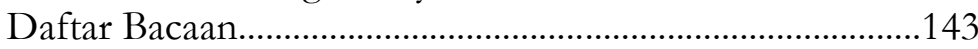

Penulis tidak menemukan edisi cetakan pertama sampai ketujuh buku ini, karena itu penulis tidak mengetahui apakah buku ini mengalami revisi dari cetakan pertama sampai kedelapan. Cetakan kedelapan ini pun hanya penulis temui di Pustaka Nasional Republik Indonesia, lantai kelima, bagian koleksi dan buku-buku langka, pun hanya bisa diphoto copy.

Dari segi sistematika (uslub) yang digunakan oleh Rangkuti dalam menafsirkan surah al-Fatihah adalah dimulai dengan penjelasan tentang alFatihah. Kemudian menjelaskan maksud masing-masing ayat dengan katakata yang dirangkainya setelah melakukan shalat tahajjud. Selanjutnya 
Kandungan al-Fätihah Karya Bahrum Rangkuti

(Koherensi al-Fätihah dengan Pancasila)

diuraikan kandungan surah al-Fatihah ke dalam bab-bab setelahnya sampai akhir.

\section{Pemikiran}

Buku Kandungan Al-Fatihah merupakan wujud dari hasil diskusi dan perdebatan Rangkuti dengan kedua temannya, yakni Amin Suroso dan Sumantri. Tema yang menjadi kajian perbincangan mereka adalah seputar koherensi teologis Islam dengan cita Pancasila sebagai dasar negara. Adapun sumber yang digunakan sebagai landasan kajian tersebut adalah surah alFatihah. Ketiganya melakukan eksplorasi mendalam terhadap kandungan surah al-Fatihah yang merupakan induk isi Al-Qur'an secara utuh dengan menggunakan visi kebudayaan, kemudian menghadapkannya dengan cita Pancasila sebagai upaya dialog guna memperoleh nilai dan hakikat kerohanian pada Pancasila, sebagaimana yang ditulis oleh Rangkuti: “Adalah maksud pengarang menafsirkan al-Fatihah dengan visi kebudayaan dan lalu menghadapkannya dengan nilai-nilai Pancasila supaya oleh konfrontasi yang jujur antara sumber cita itu dapatlah menjelma kiranya nilai dan hakikat kerohanian pada Pancasila." Jadi, bisa disimpulkan bahwa dialog antara Rangkuti dengan kedua temannya bermaksud mengintegrasikan dua hal; pertama, al-Fatihah sebagai firman Allah; kedua, Pancasila sebagai dasar negara, agar diperoleh sinkronisasi keduanya dalam kehidupan berbangsa dan bernegara dan tidak ada pertentangan antara Pancasila dengan nilai-nilai ketuhanan yang di representasikan dalam surah al-Fatihah.

\section{PENUTUP}

Berdasarkan hasil penelitian ini yang dikaji dari buku Kandungan alFatihah karya Bahrum Rangkuti, menunujkkan bahwa tidak ada pertentangan antara Pancasila dengan Islam. Rangkuti melalui bukunya membuktikan tentang koherensi antara Pancasila dengan surah al-Fatihah, di mana surah ini merupakan salah satu surah yang terdapat dalam al-Qur'an dan menjadi induk 
(ummu al-Qur'an) sebagai representasi dari seluruh kandungan al-Qur'an secara universal.

Dilihat dari aspek penafsiran al-Qur'an, adapun pendekatan yang digunakan dalam buku Kandungan al-Fatihah karya Bahrum Rangkuti ini adalah dominan ke ra'yi di samping juga terdapat beberapa penafsirannya menggunakan tafsir bi al-ma'tsur dengan merujuk kepada beberapa ayat alQur'an dan pendapat ulama terdahulu.. Metodenya adalah tablili, dan coraknya ialah adab al-ijtima'i. Sedangkan pemikirannya yang menarik bagi penulis adalah Rangkuti mencoba mengungkap keselarasan antara al-Fatihah sebagai hukum Tuhan dengan Pancasila sebagai hukum manusia. Menurutnya al-Fatihah dan Pancasila memilki kesesuaian dalam menata kehidupan berbangsa di Indonesia. Jadi, inti dari ajaran al-Fatihah pada dasarnya juga diakomodasi dalam Pancasila.

\section{DAFTAR PUSTAKA}

Bumi Bebas. (2007, Juni 21). Retrieved Juli 1, 2019, from bumibebas.blogspot.com.

Pengertian Marga dan Tarambo . (2008, Juli 29). Retrieved Mei 10, 2019, from http://silitonga-ku.blogspot.com.

Abidu, Y. H. (2007). Dirasat wa Mabahits fi Tarikh al-Tafsir wa Manahij alMufassirin. (A. M. Qadirun Nur, Trans.) Jakarta: Gaya Media Pratama.

Al-Farmawi, ‘. a.-H. (1977). al-Bidayah fi al-Tafsir al-Maudu'i. Mesir: Maktabah Jumhuriyah.

B. Setiawan, d. (2004). Ensiklopedi Nasional Indonesia (IV ed.). Jakarta: PT. Delta Pamungkas.

Baidan, N. (2000). Metodologi Penafsiran al-Qur'an . Yogyakarta: Pustaka Pelajar. Ihsan, Z. (1980). Ensiklopedi Indonesia . Jakarta: : Ikhtiar Baru .

Matondang, D. B. (2018, Maret 21). Din Syamsuddin: Ajaran Islam Sesuai dengan Nilai Pancasila. Retrieved Juli 1, 2019, from http://news.detik.com. 
Kandungan al-Fätihah Karya Bahrum Rangkuti

(Koherensi al-Fätibah dengan Pancasila)

Rangkuti, B. (1976). Kandungan al-Fatihah (VIII ed.). Jakarta: Bulan Bintang.

Taimiyah, I. (1996). Al-Siyasah al-Syar'iyyah. Beirut: Dar al-Kitab al-Arabiyah.

Thameem, U. (2000). Metodologi Tafsir al-Qur'an Kajian Kritis, Objektif dan Komprehensif. Jakarta:: Riora Cipta. 